\title{
THE GREEN LINE IN CYPRUS: EXTERNAL BORDER OR INTERNAL DISCONTINUITY OF THE EU?
}

\author{
Pierre Le Mouel \\ Département de Géographie - équipe HABITER, Université de Reims Champagne-Ardenne \\ 57 rue Pierre Taittinger, 51571 Reims Cedex: France \\ pierre.le-mouel@univ-reims.fr
}

\begin{abstract}
Defining the Cyprus Green Line is a contested issue. Since the accession to the European Union of the Republic of Cyprus (RoC) in 2004, the EU has had to balance between two conflicting definitions of the Green Line. The first, set by international law and the United Nations (UN) resolutions, is that of a peace line that is only a temporary internal discontinuity within the RoC, separating both communities until a settlement is agreed. The second, championed by Turkey and the Turkish Cypriots' pseudo-state, is that of an international border between both independent communities. The EU has had to apply both definitions at the same time, legally and pragmatically, which has heavily hindered its own peacebuilding efforts in Cyprus and reduced its actorness in Eastern Mediterranean geopolitics.
\end{abstract}

Keywords: border, conflict resolution, Cyprus, European Union, Green Line, Turkish Cypriot, Turkey.

\section{Introduction}

The European Union's (EU) enlargement of 2004 extended its borders towards the East and in the Mediterranean and brought new challenges to its bordering abilities. As Cyprus joined the EU a week after the proposed Annan Plan for a reunified island was rejected through referendum by the Greek Cypriot Community, the European institutions had to take into account the complex legalities surrounding the Cyprus Green Line. Drawn up across the island in 1974 after Turkey's military interventions in Cyprus, the Green Line is a Demilitarized Zone (DMZ) administered by the United Nations (UN) that now separates the two communities: Greek Cypriots to the south and Turkish Cypriots to the north. The Republic of Cyprus (RoC), established as a bi-communal state in 1960 and now predominantly Greek Cypriot, is still the only recognized state on the island with its northern part considered illegally occupied by Turkey and the self-proclaimed Turkish Republic of Northern Cyprus (TRNC) being recognized by no other country than Turkey. The Green Line is neither an international border nor an internal division of the RoC, yet it separates two distinct states and populations. This ambiguity remained as the RoC joined the EU on behalf of all Cypriots. The whole island of Cyprus is now EU territory as it is the de jure territory of the RoC, but the acquis communautaire has been suspended north of the Green Line by the European Council until a settlement is reached. 
This article analyses the two contradictory definitions of the Green Line coexisting within the framework of the EU and how this ambiguity impacts the EU's peacebuilding actions in $\mathrm{Cy}$ prus. While a lot of focus has been put on international law that considers the Green Line simply as a peace line within the RoC (Drevet, 2011), this approach maintained by states and international organisations tends to disregard the realities of a discontinuity that has greatly evolved since it opened in 2003. This is why the first part of this article will show how the Green Line operates de facto like an international border which in turn pushed the $\mathrm{EU}$ to use elements from its external border policy to regulate the Green Line through its Regulation 866/2004 (EUCO, 2004). Because the EU still remains attached to the UN's framework for conflict resolution in Cyprus which defines the Green Line as a temporary DMZ within the RoC and since 2004 within the EU's territory, it perpetuates the ambiguity by applying both definitions at the same time to the Green Line. The following part of the article studies how this lack of a single clear definition creates conflict between Eastern Mediterranean states who use the definition that best suits their regional ambitions. The 2020 presidential election in the TRNC has shown that even within the Turkish Cypriot Community the question hasn't been set and to what extent Turkish president Erdoğan is willing to commit to the Green Line being an international border. Finally, this article will address the paradox the EU has adopted by refusing to completely adhere to one definition and the choice it must make to bring the island closer to a definite solution.

To do so, it will be based on a qualitative study of the two Regulations that created the EU's legal framework defining the Green Line, Regulations 866/2004 (EUCO, 2004) and 389/2006 (EUCO, 2006) as well as the annual reports on the implementation of each Regulation (EC, 2004, 2019), written by the Commission for the Council and the European Parliament. This analysis will be accompanied by two interviews of civil servants of the Commission conducted in Brussels in January 2020, one being the EU supervisor of the Financial Instrument of Regulation 389/2006 and the other being legal advisor to the Cyprus Settlement Support Unit. To complete the study of these European texts, this article is also based on a fieldwork conducted in Cyprus during the first semester of 2018 for my Master's thesis on the border effects of the Green Line on Cypriot communities. The approach used is that of a geopolitical analysis: studying the conflictual or cooperative interactions between actors to define and control an area and the impact those interactions have on the structure of said area (Rosière, 2007).

\section{A border in all but name}

Between 1974 and 2003, the Green Line was a closed off DMZ patrolled by the UN Peacekeeping Force in Cyprus (UNFICYP). Highly restrictive travelling conditions were set to insulate both communities from each other. In 2003, in the midst of an economic crisis in northern-Cyprus and under the pressure of Turkey, the TRNC authorities unilaterally opened three checkpoints and lifted all travelling restrictions. From this moment, it became evident that both sides regarded the Green Line quite differently. The TRNC set border checks to regulate Greek Cypriots coming to northern-Cyprus with a free one-day visa delivered by border guards at the checkpoints. The RoC did not welcome this unilateral opening as Greek Cypriots had to show their passports and get a visa to move within their own state's legal territory. Nonetheless, the Cypriots were more enthusiastic about crossing the border than they were reluctant to tacitly recognize the TRNC by submitting to its travel restrictions. Within two weeks of the checkpoints being opened, a quarter of the island's population had already crossed the Green Line (Ker-Lindsay, 2011). The number of Cypriots cross- 
ing the Green Line has only increased, reaching a total of 3.4 million crossings in 2018 (EC, 2019). The TRNC considers the Green Line as an international border and treats it as such, conducting systematic passport checks, while their Greek Cypriot counterparts often let people pass after a glance at their passport without registering the crossing.

Even though only the TRNC and Turkey view the Green Line as an international border, the Turkish Cypriot authorities still have a de facto control over their border policy. The Turkish military presence in Northern Cyprus, estimated at 35,000 soldiers for a population of approximately 300 thousand TRNC citizens, prevents RoC forces from entering Northern Cyprus, thus granting the TRNC virtual independence on its claimed territory. This gives the Green Line a second aspect of an international border: it is the extent of both countries' effective sovereignty. The laws are different on both sides of the island and two distinct police forces apply the law in their own territory. Both territories have state structures - even though the TRNC institutions are not recognized by the international community - and can pass laws and exercise power freely in their respective territories. It is still important to recognize the fact that RoC's laws technically apply to Northern Cyprus, but Cyprus police forces cannot enforce them. In view of this issue, the EU has suspended the acquis in Northern Cyprus, described as 'areas of the Republic of Cyprus in which the Government of the Republic of Cyprus does not exercise effective control' (EUCO, 2004, p. 1).

Even though legally the island of Cyprus is the sovereign territory of the RoC, an EU member state, the TRNC functions as a pseudo-State that only lacks recognition (Bryant \& Hatay, 2020). It has its own functioning institutions, with regular free and fair elections in a semi-presidential republic as well as dedicated public services. It can levy taxes and enforce its own laws, even though it is heavily reliant on Turkish aid and military presence, making it a quasi-state (Kolstø, 2006). Moreover, the TRNC's currency (the Turkish Lira) is distinct from that of the RoC (the Euro) and while Euros are accepted in most touristic areas of Northern Nicosia, the Turkish Lira cannot be used in the south, further increasing the divide between both sides of the Green Line.

The Green Line is considered as an international border only by Turkey and the TRNC, but because of Turkey's military presence, it functions as such. This definition of the Green Line has been reinforced by the EU's decision to suspend the acquis in Northern Cyprus, emphasizing the Green Line's function as the limit between two distinct legal, economic and political territories (Foucher, 1991).

\section{Symbolism and bureaucracy, setting barriers to intra-island mobility and trade}

We have seen how the Green Line functions as a border rather than a discontinuity within the RoC's territory through the TRNC's ability to impose its unilateral definition thanks to Turkey's military presence. There are also elements from the RoC that tend to define the Green Line as an international border. In order to enforce the non-existence of the TRNC, the RoC has to conduct border checks and set bureaucratic boundaries to limit access to the south for TRNC residents who do not possess valid identification delivered by a recognized state.

Because the TRNC isn't recognized, any legal document it delivers is considered void, its citizens who do not possess an ID card or passport delivered by the RoC cannot legally enter any country other than Turkey which recognizes the TRNC. Any third-country citizen who enters Cyprus through the TRNC is considered as having unlawfully entered into RoC territory and has no right to move to the south of the island under the control of the RoC. Those two legal issues, caused by the 
fact that the TRNC is unrecognized and therefor that the Green Line is simply an internal discontinuity within the RoC, force the RoC to set checks at the Green Line's crossing points as if it was an international border. The same principle applies to goods produced in Northern Cyprus. As no recognized institution can create legal documents to certify goods, they cannot cross the Green Line into the south, so the RoC controls vehicles to check for any imported goods. Cars with license plates from the TRNC cannot legally be used in the RoC so the Cyprus police has to control and sometimes prevent north-south mobility as if they were enforcing an international border. These bureaucratic obstacles constitute effective barriers to intra-island trade (Hatay, Mullen \& Kalimeri, 2008) which further divides Cyprus along the Green Line. It is important to keep in mind that even with such barriers, trade is still conducted between north and south (the Cyprus Customs and Excise Department has reported a total of 4.9 million Euros worth of trade goods entering the south in 2018) and the number of annual crossings of the Green Line exceed the population of both sides (1.63 million crossings into the north by Greek Cypriots and 1.75 million by Turkish Cypriots in 2018 according to the Turkish Cypriot community).

Furthermore, there are elements shared by both the RoC and the TRNC that work together to create this impression that the Green Line is a de facto international border. In all three dimensions of the border (institutional, material and symbolic; Reitel, 2004; Blondel, 2016) the Green Line can easily be defined by both sides as a border between states rather than between communities. We've seen how the Green Line is institutionalized as a border with the use of border checks, customs controls and administrative boundaries to limit crossings. When looking at the materiality of the Green Line, the ambiguity remains. Of course, the most obvious aspect of it is the No Man's Land that divides the island and more importantly the capital city of Nicosia. A 47-year-old wall that cuts through streets and the countryside with abandoned buildings inside the DMZ serves as a constant material reminder of the division between both communities and their respective territories. With regard to the border functions that we previously discussed, in order to process the crossings, the RoC has built border infrastructures and customs offices to host the Cyprus police officers who conduct the checks, just as the TRNC has built their own. Both sides have built the infrastructures needed to administer conflictual international borders. There remains nevertheless a material difference between the northern and southern sides of the Green Line. On the TRNC's side, the wall is built with concrete blocks as a lasting solution, forming fortress-like ramparts that cannot be approached by anyone except military personnel. On the RoC's side, the structures that were put up during the 1960s intercommunity conflict are still up. They are still made of drums and barbed wire as if ready to be taken away as soon as a solution is found. The southern side of the wall is also accessible and street artists have decorated every portion of the wall that have created cul-de-sacs in south Nicosia.

The symbolism that permeates the Green Line also serves the purpose of emphasizing the differences between both sides. Nicosia, being the only densely populated area of Cyprus cut by the Green Line, is the most affected area in which symbols are used on both sides to materialize how each community views the Green Line. By doing so, those symbols create a more evident rift between northern and southern Nicosia. Each side of the border hosts numerous flags, always by pairs. On the northern side the TRNC flag is always next to a Turkish flag while on the other side RoC flags are always with a Greek flag. The fact that both side mirrors each other by always accompanying their state flag with that of the 'motherland' has a strong impact on the way both communities view the issue. Greek Cypriot nationalists consider the northern part to be their own, but by refusing to show their passport which would tacitly mean recognizing the existence of the TRNC, they actively maintain the wall that prevents them from seeing the other community, thus 
reinforcing the Green Line's borderity (Newman, 2003). On the other hand, the TRNC uses a saturation of flags in public spaces to materialize their legitimacy and underpin the idea it is equivalent to that of the RoC.

Through those aspects, the Green Line more closely resembles an international border rather than a simple internal discontinuity. Even if the RoC and Greek Cypriot nationalists only view Northern Cyprus as being their territory that is occupied by Turkey, they still have to apply some elements of border control in order to enforce their refusal to recognize the TRNC as a State.

\section{Defining the Green Line through European legal instruments}

In face of this lack of a functional definition to the Green Line, the EU had to react quickly in 2004. The Annan Plan, that was set to establish a new federal RoC that could access the EU, was rejected by the Greek Cypriot community on the $24^{\text {th }}$ of April 2004 as the RoC was set to officially enter the EU on the $1^{\text {st }}$ of May of the same year (Palley, 2005; Hadjidemetriou, 2008). On the $27^{\text {th }}$ of April, the European Council issued a statement recognizing the Turkish Cypriot vote in favor of the Annan Plan and of joining the EU Council, 2004). With these conclusions, the European Council had to accept that the Turkish Cypriot community would remain outside of the EU under international law, which in turn lead to the EU suspending the acquis in Northern Cyprus in their Regulation 866/2004, also called Green Line Regulation that created a legal framework for the Green Line. Again, we see here the ambiguity as the EU considers the whole island of Cyprus as EU territory but has suspended all EU laws in the areas north of the Green Line to take into account the realities of the situation in Cyprus. In the preambulatory articles of the Green Line Regulation, the EU expresses clearly that the Green Line 'does not constitute an external border of the EU' (EUCO, 2004, p. 2). Because Northern Cyprus is de jure outside of the EU Single Market, the Green Line becomes an unofficial external border of the EU as goods that cross from north to south have to be checked and customs applied. The first step in setting up the Green Line Regulation was to forbid the crossing of any goods into the Single Market from the TRNC, thus reinforcing again the Green Line as a border instead of an internal discontinuity within the EU's territory.

The EU's approach to the Green Line is twofold. The legal basis set by the Green Line Regulation is heavily influenced by the EU's external borders framework, even though the Commission strictly adheres to international law by considering Northern Cyprus as the legal territory of the RoC and of the EU. Regulation 866/2004 establishes conditions for the crossings of goods into the south, dependent on their respect of EU norms, which necessitates border controls to be undertaken by the RoC as if it was an international border (Ersözer, 2019). Such checks also need an institution that can deliver the official papers set by the Green Line Regulation. Because the EU cannot discuss with the TRNC, even though they exert effective control over the bureaucracy in Northern Cyprus, they had to find an institution created before the conflict that was still operational in the TRNC. The Turkish Cypriot Chamber of Commerce, established in 1954, was chosen as the only organization who can deliver the official documentation regarding EU norms for goods produced in Northern Cyprus (EC, 2004). As the years passed, more and more goods were authorized into the south through modifications to the Green Line Regulation. While the RoC isn't part of the Schengen Agreement because of the Cyprus issue, the EU regularly asks the RoC to increase its control over the Green Line to prevent illegal immigration into the EU. Even if the EU can set rules for goods and even for persons (in 2014 the TRNC removed the need for a visa to enter into the north for EU citizens), it cannot enforce them and is entirely reliant on the RoC who remains sover- 
eign over its territory. In the annual reports on the implementation of the Green Line Regulation, the Commission repeatedly asks the RoC to increase its use of border guards to patrol the Green Line but the RoC refuses as it would mean giving credit to the idea that the Green Line functions as an international border.

Since the Council's conclusions of April $27^{\text {th }} 2004$, the official goal set by the EU with regards to the Green Line is to work towards opening it as much as possible, in order to reduce the Turkish Cypriot community's isolation after their vote in favor of the Annan Plan, but also in order to change the Green Line into a de facto internal discontinuity within EU territory. In order to do so, the EU has had to set a clear legal framework that used elements from its external border policy from which to work towards a fully opened Green Line.

The second part of the EU's strategy towards the Green Line is to strengthen its ties with the Turkish Cypriot community and develop their rights to gradually get to a complete application of the acquis once the Cyprus issue is solved and the whole island (with the exception of the British Sovereign Base Areas) becomes effectively EU territory. Because of the lack of recognition for the TRNC, the EU is limited in potential official Turkish Cypriots partners and has to ask permission from the RoC for any projects conducted in Northern Cyprus. The EU has a specific budget to develop Northern Cyprus that was set aside to help reduce the economic differences between the Turkish Cypriot community and the Greek Cypriot community after the joint accession under a federal RoC. As the Annan Plan was rejected, the EU decided to continue this financial aid and set it officially as a financial instrument established through Regulation 389/2006 (EUCO, 2006). In the 2014-2020 EU Budget, approximately 30 to 35 million Euros were allocated to this financial instrument that mainly targeted projects in education, water treatment and improving standards of production in Northern Cyprus. This last point is the main goal as it serves to increase products that meet EU norms on goods and that can therefor enter the south by respecting the Green Line Regulation. A civil servant of the EU Commission working on the application of the Green Line Regulation explains how in 2019, the Commission increased its efforts in helping Turkish Cypriot fishers get refrigeration machinery that met EU standards in order for them to expand their production and increase their trade with the south as fresh fish products are allowed by the Green Line Regulation. To operate the financial instrument and the Green Line Regulation, the Commission established the Cyprus Settlement Support Unit (CSSU) that has changed hands within the Commission. At first it operated under Directorate General ENLARGEMENT ${ }^{1}$ as the Financial Instrument was planned before the accession of Cyprus to the EU as any other financial aid distributed to candidate countries. However, once the RoC entered the EU, it refused to consider Northern Cyprus as a territory outside of the EU working towards joining it, so the unit was attached to DG REGIO working on regional integration to emphasize the fact that Northern Cyprus is a region like any other of the EU according to another civil servant from the CSSU. It is now part of DG REFORM ${ }^{2}$ as a specific mission outside the usual responsibilities of the DG, but this change of hands serves to show the RoC that any efforts undertaken towards the Turkish Cypriot community in Northern Cyprus are considered as tools to develop communities within the territory of the EU. It should also be added that with regards to the Financial Instrument to the Turkish Cypriot community, the budget has to be agreed to unanimously in the Council of the European Union, giving the RoC final say in how the money is spent in Northern Cyprus.

\footnotetext{
${ }^{1}$ It is now called DG NEAR for Neighborhood and Enlargement Negotiations.

${ }^{2}$ Structural Reform Support since January 2020.
} 
Even though the EU has developed a specific European framework for the Green Line, using elements from its external border policy, it remains reliant on the RoC's application of this regulation. In order to implement as effectively as possible this framework, the EU set a specific budget for the Turkish Cypriot community that end up reinforcing the Green Line as a simple discontinuity within the $\mathrm{EU}$ as the RoC has the last word on the budget of this financial instrument which has been moved from DG ENLARGEMENT to DG REFORM. Those two regulations show how the EU's Cyprus policy takes into account the reality of the situation in Cyprus which forced it to consider the Green Line as functioning as an external border but still adheres to the legal view that there is no border in Cyprus, only an internal discontinuity.

\section{The geopolitics of a contested discontinuity and Turkey's renewed influence in Cyprus}

The main problem that arises because of the lack of universally recognized definition to the Green Line's status is the possibility for regional actors to choose which definition best suits their interests. On the one hand, the RoC cannot abide by any other definition than a simple peace line across its legitimate territory. The Turkish Cypriot community, on the other hand, is still divided about which definition to choose. The nationalist elements in Northern Cyprus, mainly represented politically by the National Unity Party (UBP), consider the TRNC is a fully independent state. Their founder and leader from 1975 to 2005, Rauf Denktaş, used his influence in Ankara to guarantee Turkish aid that maintained the Turkish Cypriot community until he declared the creation and independence of the TRNC in 1983. Turkey's influence in Northern Cyprus has remained the condition by which the TRNC has been able to establish a de facto independent state, but this influence came at a cost. Except for a short period around the year 2000 when the ruling AKP party in Turkey had serious ambitions of joining the EU, Turkey has increased the Turkish Cypriots' dependence on what was viewed as ana vatan, the 'motherland'. Already in 1975, only a year after the Turkish military interventions in Cyprus in the summer of 1974 that lead to the creation of the island-wide Green Line, Ankara sent Anatolian settlers to repopulate Northern Cyprus as Turkish Cypriots emigrated to the United Kingdom or the United States (Hatay, 2005). Some of those settlers and their descendants now even put forward a third definition to the Green Line: an international border between the RoC and Turkey. Since Turkey's influence amongst the Turkish Cypriot community was officially recognized in 1960 when the RoC got its independence from the British Empire by inviting Turkey to sign the treaties that created the RoC as a guarantor, Turkey has had a strong say in the negotiations. The last round that took place in 2018 in Crans-Montana collapsed once the issue of Turkish military presence in Northern Cyprus was brought up as Turkey refused to discuss any evacuation of its troops from Cyprus. With such strong influence and ties to the Turkish Cypriot community, Turkey is clearly what can be described as a kinship state (Byrne, 2006). Turkey acts as a guarantor to the TRNC and controls its Anatolian diaspora in Northern Cyprus enough to go against the TRNC's president or institutions. This has been demonstrated in January of 2018 when the newspaper Afrika criticised Turkey's military operation in Afrin, Syria. President Erdoğan issued a statement saying '[his] compatriots in Northern Cyprus should give the necessary response to this'(Wesselingh, 2018, December 16). This sparked a violent protest against the newspaper's offices, with eggs and rocks thrown. When the President of the TRNC, Mustafa Akıncl, came to the spot of the protest he was himself molested. 
Even though it could be argued that a solution in Cyprus would be in Turkey's interest (Mullen, Çılsal \& Antoniadou Kyriacou, 2010), since President Erdoğan came to power, Turkey has increased its attacks on the TRNC's supposed independence. As said above, Erdoğan has a strong control over some elements within the Turkish Cypriot community. He has also attacked the legitimacy of the democratically elected President of the TRNC, Mustafa Akıncı, in October 2019. When Akıncı criticised Turkey's operation in Syria, Erdoğan replied '[he] must know his limits. The seat he sits on is not something he acquired. It was won by the intervention of the Turkish Republic.' (Christou, 2019, October 13). More recently, during the 2020 TRNC presidential election, Erdoğan gave full support to Ersin Tatar, the UBP's candidate running against Akıncı on a platform of equal sovereignty between the RoC and the TRNC. The Turkish president went so far as to openly state that the only solution in Cyprus is a two-state solution, days after Tatar won the elections. Turkey's position is clearly in favor of considering the Green Line as an international border.

The reason for this rhetoric from Ankara lies not only in Turkey's history with Turkish Cypriots, but also with the hydrocarbons issue in the Eastern Mediterranean. While the RoC and the EU adhere to the principles of the United Nations Convention on the Law of the Sea (UNCLOS), Turkey has notified the UN that is shall not take part in UNCLOS. This Convention defines between all signatories the way in which maritime boundaries should be drawn, and more importantly, how Exclusive Economic Zones (EEZ) are to be mapped. Turkey has officially taken the stance of only drawing maritime borders through bilateral treaties (Georges, 2012). As it stopped recognizing the RoC in 1974 (it considers the RoC to be illegitimate since it is constitutionally obliged to represent both communities but only Greek Cypriots are represented in the current RoC's institutions), Turkey has signed a treaty with the TRNC to get access to the Cyprus EEZ. Since the 2010s, Turkey has sent various exploratory missions in RoC's waters to conduct prospections before exploiting the hydrocarbons reserves recently discovered in the Eastern Mediterranean (Gürel, Mullen \& Tzimitras, 2013; Gürel, Tzimitras \& Faustmann, 2014).

On the other hand, the EU and the signatories of UNCLOS still consider the whole island of Cyprus (with the exception of the British Sovereign Base Areas or SBA) to be the legitimate territory of the RoC, and by extension, the island's EEZ can only be administered by the RoC. Turkey's operations in the RoC's EEZ are considered as infringing upon RoC's sovereignty and have caused Greece and France to increase their military cooperation with the RoC in the summer of 2020 after a Turkish prospector vessel, escorted by the Turkish navy, unlawfully entered Greek and Cypriot waters. This conflict in the Eastern Mediterranean is only perpetuated by the fact that the actors do not agree on a shared definition of the Green Line that would set the status of the TRNC and of the RoC's territory.

\section{The limits of European peacebuilding efforts within the confines of international law}

Now that the ambiguities of the Green Line's status have been explained as well as the impact it has on the geopolitics of the Eastern Mediterranean, it is important to analyze the EU's peacebuilding efforts in Cyprus. As previously explained, the EU has created a legal framework around the Green Line in order to ensure the cohesion of the Single Market and the EU's territory, while putting in place what it considers the best conditions for a rapid integration of Northern Cyprus 
into the EU. The EU has consequently adopted a passive role in the Cyprus issue, working towards creating the conditions for accession, but not for a resolution to the conflict. During the heating up of tensions in the Eastern Mediterranean in 2020, France has reiterated its position shared by the EU that a solution can only be found within the boundaries of the UN's conflict resolution framework established through its Security Council resolutions on Cyprus. However, this framework has found itself stuck in a paradox (Thierry, 2012). In Resolution 360 (1974), the UN's Security Council (UNSC) refuses to accept the policy of fait accompli following a military intervention prohibited by the UN's Charter's article 2 (UNSC, 1974). Turkey's second Atilla operation in August 1974 pushed to Nicosia in order to create a homogeneous territory for the Turkish Cypriot community, delineated by the Green Line. The UN couldn't recognize the validity of such an unlawful military operation and, in consequence, set in its resolutions not to consider the Green Line as anything else than a peace line, with the intent of finding a solution that would remove the Green Line and enable refugees to return to their homes. In 1977, a first round of intercommunal negotiations under supervision by the UN set the idea that a solution in Cyprus would have to be federal, where each community has its own federative state with its own territory within a federal RoC whose territory would again be the whole island (except the British SBA). This solution was reiterated in 1992 once it had become evident that both south and northern Cyprus were now ethnically homogeneous (UNSC, 1992). Here lies the paradox in which the UN put itself. It cannot recognize the Green Line as an official boundary as it would mean recognizing the effect of an unlawful military intervention, but the only solution is to recognize the Green Line as an internal border between the federative states of each community within a federal RoC, even if some geographical modifications are done to the Green Line.

Any European peacebuilding effort that recognizes the UN's framework as the only applicable is bound to entangle itself in the same paradox. This explains why the EU can only prepare Northern Cyprus for its integration in the EU if a solution is found. Its peacebuilding efforts lay mostly in the Europeanization of Northern Cyprus through the increasing implementation of the acquis north of the Green Line (Kyris, 2009). While it officially considers the UN as the only institution to supervise the peace process, it has developed its own rhetoric of peacebuilding through building trust and cooperation between both communities, mostly through commercial contacts. But even this peacebuilding narrative falls into another paradox that again paralyzes any European efforts to influence the negotiations towards a resolution. The EU has decided on a passive strategy by not choosing one definition to the Green Line but by applying both at the same time. As the EU fully adheres to the UN's paradoxical efforts to find a solution, it cannot recognize the Green Line as anything else than a peace line or, in the case of a federal solution, an internal discontinuity between federative states within the RoC. Yet, when faced with the realities of the Green Line, the EU had to suspend the acquis in Northern Cyprus, which de facto and also de jure made the Green Line an external border of the EU territory on which EU laws apply, even if Northern Cyprus is still theoretically EU territory. This legal decision established through Regulation 866/2004 meant that the EU has, to a certain extent, to operate the Green Line as it does its external borders.

The EU's legal decision to adhere to the principles of the UN framework and pragmatic decision to suspend the acquis in Northern Cyprus has created strong limits to the EU's influence on the Cyprus issue. The implementation of its own rules regarding the Green Line are dependent on the RoC willingness to apply them, even though the RoC has a vested interest in the negotiations and maintaining the status quo. 


\section{Conclusions}

Seventeen years after the RoC entered the EU, the Green Line remains a contested discontinuity. Both definitions (internal discontinuity or external border of the EU) coexist through the legal frameworks set by international law or by the EU itself. As long as no universally accepted definition is set, regional actors perpetuate this ambiguity to further their own geopolitical goals. The two main actors being the EU, of which the RoC is a member-state, and Turkey have each applied their own definition. The EU remains attached to international law while Turkey recognizes the TRNC as a sovereign state. This opposition is reflected within the Turkish Cypriot community itself between Turkish Cypriots in favor of a solution and accession to the EU on one side and Turkish Cypriot nationalists who consider their independence as effective and a fact that should be recognized internationally on the other. The EU reinforces the ambiguity between both definitions by acting pragmatically. It recognizes the UN framework for any solution in Cyprus but uses elements of its external borders policy to take into account the realities of the Green Line.

To a varying degree of honesty, all actors involved in the Cyprus issue and its resolution agree that a permanent solution should be found. Finding such a solution would mean setting for one of the two definitions and getting the chosen definition universally recognized. However, too many actors still profit from the status quo in which both definitions coexist Turkey can still operate in the RoC's waters that it doesn't recognize if it keeps its military in Northern Cyprus. The TRNC can operate as a fully functional pseudo-state while Turkey's military defends its unrecognized sovereignty over Northern Cyprus. The RoC, aided by Greece, can use the UN's framework to keep affirming it is the only sovereign state on the island and influence the EU's response to Turkey ${ }^{3}$. Furthermore, as the only sovereign state in Cyprus, the RoC can control to what extent EU rights are applied to Turkish Cypriots and keep its upper hand in negotiations for a solution in Cyprus. The EU does not profit per se from the status quo as it has to balance between the RoC's veto and the reality of the Green Line to maintain the integrity of the Single Market and its territory.

The main issue for the EU is that the European institutions and member-States always reaffirm their recognition of the UN as the only institution responsible for brokering a deal between both communities. The EU adopted a passive role in the Cyprus conflict with no say in the negotiations and a minor role as a mediator, even though it has to suffer the consequences of the Green Line. By keeping this passive stance, the EU is forced to work with both definitions at the same time. Its only long-term goal is to create a situation in Northern Cyprus where a federal solution would have the least negative effects, but it doesn't actively work towards achieving a solution, whatever it may be. In the Cyprus issue, even though it affects the EU's territorial integrity, as technically a foreign military power unlawfully is occupying EU territory in Northern Cyprus, the EU is dependent on the RoC, limited in its response by international law and can only wait for the UN to break the endless cycle of failed negotiations while Turkey ramps up its presence in the Eastern Mediterranean.

The Cyprus issue shows how the EU isn't an international actor that can set its own independent goals and work to achieve them in the geopolitics of the island of Cyprus, thus limiting its actorness on the Mediterranean stage (Richard \& van Hamme, 2013). It can only recognize common goals from its member-states and support them in reaching their goals. In order to change that, the EU must be able to take an active role by choosing a clear definition to the Green Line, deciding on an autonomous path that isn't reliant on a paradoxical framework and working towards

\footnotetext{
$\overline{3}$ In the autumn of 2020, Cyprus vetoed EU sanctions on Belarus because it considered the sanctions on Turkey to be too weak.
} 
breaking the status quo instead of letting other actors impose it to the EU, especially through military means. The Cyprus example is a strong deterrent to Moldova and Ukraine's accessions as they are also entangled in an internal conflict with an unrecognized state supported by a foreign military presence. While Turkey has been a candidate to EU accession since 1987 and an ally of major EU countries inside NATO, Russia is neither and a solution might be harder to find with such a belligerent country. Actively working towards and finding a lasting solution in Cyprus would add to the EU's credibility as a geopolitical actor not only in the Eastern Mediterranean but in Eastern Europe as well.

\section{References}

Blondel, C. (2016). Aménager les frontières des périphéries européennes : la frontière Serbie/Croatie à l'épreuve des injonctions à la coopération et à la réconciliation. Tours: Université de Tours.

Bryant, R., \& Hatay, M. (2020). Sovereignty suspended: building the so-called state (1st edition). Philadelphia, PA: University of Pennsylvania Press.

Byrne, S. J. (2006). The roles of external ethnoguarantors and primary mediators in Cyprus and Northern Ireland. Conflict Resolution Quarterly, 24(2), 149-172. https://doi.org/10.1002/crq.164

Christou, J. (2019, October 13). Tatar to discuss Akinci resignation Monday, Erdogan says he exceeded his limits (Update 2). Cyprus Mail. Retrieved from https://cyprus-mail.com/2019/10/13/tatar-to-discuss-akinci-resignation-monday-erdogan-says-he-exceeded-his-limits-update2/

Council (2004). Council Conclusions on Cyprus, DG E I 8907/04 (No. 8907/04). Brussels: Council of the European Union.

Drevet, J.-F. (2011). Chypre entre l'Europe et la Turquie. Paris: Karthala.

EC (2004). Commission Decision of 7 July 2004 on the authorisation of the Turkish Cypriot Chamber of Commerce according to Article 4(5) of Council Regulation (EC) No 866/2004. Brussels: European Commission.

EC (2019). Report from the Commission to the Council Fifteenth report on the implementation of Council Regulation (EC) No 866/2004 of 29 April 2004 and the situation resulting from its application covering the period 1 January until 31 December 2018. COM/2019/323 final. Brussels: European Commission.

Ersözer, F. (2019). The Green Line Regulation and its potential for cooperation in Cyprus (PCC Report No. 9). Oslo: PRIO Cyprus Center.

EUCO (2004). Council Regulation (EC) No 866/2004 of 29.4.2004 on a regime under Article 2 of Protocol No 10 of the Act of Accession (No. 866/2004). Brussels: European Council.

EUCO (2006). Council Regulation (EC) No 389/2006 of 27 February 2006 establishing an instrument of inancial support for encouraging the economic development of the Turkish Cypriot community and amending Council Regulation (EC) No 2667/200 on the European Agency for Reconstruction (No. 389/2006). Brussels: European Council.

Foucher, M. (1991). Fronts et frontières : Un tour du monde géopolitique (2nd ed.). Paris: Fayard.

Georges, K. (2012). Le statut juridique des espaces maritimes de Chypre. In J. Rossetto \& K. A.-J. Ka (Eds.). La singularité de Chypre dans l'Union européenne. Diversité des droits et des statuts (pp. 161-192). Paris: Mare \& Martin.

Gürel, A., Mullen, F., \& Tzimitras, H. (2013). The Cyprus Hydrocarbons Issue: Context, positions and future scenarios. Nicosia: PRIO Cyprus Centre.

Gürel, A., Tzimitras, H., \& Faustmann, H. (2014). East mediterranean hydrocarbons. Geopolitical perspectives, markets, and regional cooperation. Nicosia: PRIO Cyprus Centre.

Hadjidemetriou, T. (2008). The 24 April 2004 referendum and the solution of the Cyprus problem (AHDR). Nicosia: Ikme; UNR129.

Hatay, M. (2005). Beyond numbers. An inquiry into the Political Integration of the Turkish "Settlers" in Northern Cyprus. Oslo: PRIO Cyprus Centre. 
Hatay, M., Mullen, F., \& Kalimeri, J. (2008). Intra-island trade in Cyprus: obstacles, oppositions and psychological barriers. Nicosia, Cyprus: PRIO Cyprus Centre.

Ker-Lindsay, J. (2011). The Cyprus problem: what everyone needs to know. Oxford: Oxford University Press.

Kolst $\varnothing$, P. (2006). The Sustainability and Future of Unrecognized Quasi-States. Journal of Peace Research, 43(6), 723-740. https://doi.org/10.1177/0022343306068102

Kyris, G. (2009). Europeanisation, EU enlargement and the Turkish Cypriot Community: developing a conceptual framework. 4th Hellenic Observatory PhD Symposium on Contemporary Greece and Cyprus, London.

Mullen, F., Çılsal, Ö. O., \& Antoniadou Kyriacou, P. (2010). The day after III. The Cyprus peace dividend for Turkey and Greece. Nicosia: PRIO Cyprus Centre.

Newman, D. (2003). On borders and Power: A Theoretical Framework. Journal of Boderlands Studies, 18(1), 13-24. https://doi.org/10.1080/08865655.2003.9695598

Palley, C. (2005). An International Relations Debacle: The UN Secretary-general's Mission of Good Offices in Cyprus 1999-2004. Portland, OR: Hart Publishing.

Reitel, B. (2004). Frontière. Hypergeo. Retrieved from http://www.hypergeo.eu/spip.php?article16

Richard, Y., \& van Hamme, G. (2013). The European Union as an Actor in International Relations. L'Espace Géographique, 42(1), 15-30. https://doi.org/10.3917/eg.421.0015

Rosière, S. (2007). Géographie politique \& géopolitique: une grammaire de l'espace politique (2nd ed.). Paris: Ellipses.

UNSC (1974). Resolution 360 (1974) of 16 August 1974. New York: United Nations Security Council.

UNSC (1992). Resolution 789 (1992) of 25 November 1992. New York: United Nations Security Council.

Thierry, D. (2012). Le statut de la ligne verte. In J. Rossetto \& K. A.-J. Ka (Eds.). La singularité de Chypre dans I'Union européenne. Diversité des droits et des statuts (pp. 41-62). Paris: Mare \& Martin.

Wesselingh, I. (2018, December 16). North Cyprus journalist takes on Turkey's mighty Erdogan. Agence France Presse. Retrieved from https://www.france24.com/en/20181216-north-cyprus-journalisttakes-turkeys-mighty-erdogan 